\title{
STUDIES ON \\ NORTH AMERICAN CARBONIFEROUS INSECTS. \\ 6. UPPER CARBONIFEROUS INSECTS FROM PENNSYLVANIA*
}

\author{
By Frank M. Carpenter \\ Museum of Comparative Zoology \\ Harvard University, Cambridge, Mass. 02138
}

This study is based on fossil insects from the Anthracite Coal Fields of Pennsylvania. In 1977 Mr. William F. Klose II, of Noxen, Pennsylvania, sent me for identification a series of fossil insects that he had collected in beds belonging to the Llewellyn Group of the Allegheny Series. Subsequently he arranged for a loan of specimens in the Reading Public Museum and Art Gallery, all of which had been collected many years ago by Claude Weston Unger in beds apparently also belonging to the Allegheny Series. The age of the Allegheny is about equivalent to that of the Late Westphalian of Europe, possibly slightly older than the Carbondale Formation of Illinois, in which the Mazon Creek nodules occur, and considerably older than the insects-bearing beds at Commentry, France. Although remains of insects are found only very infrequently in the Anthracite Coal Fields and are usually fragmentary, the specimens are of much significance because of their age.

The insects were apparently inhabitants of swampy regions. Remains of plants are well represented in both the Klose and Unger collections and are often preserved in close association with the insects. Mr. Klose has identified the plant genera Lepidodendron, Neropteris, Pecopteris, and Sphenophyllum from specimens occurring with insects on pieces of the shale. These plants were typical of the coal swamps of the Upper Carboniferous. Cockroaches were by far the predominate insects. Of the fifty specimens of insects in the collections at hand, forty-five, or $90 \%$, belong to the Blattaria, a percentage that is typical for such coal beds. Four specimens represent the orders Protodonata, Caloneurodea, and Protorthoptera, which will be discussed below. In addition, there is a specimen of a small insect [No. I1025 (K6345)] that appears to be related to

*Manuscript received by the editor September 28, 1980. 
the enigmatic Dictyocicada antiqua, from the Commentry shales; an account of this specimen will be included in another article dealing with Dictyocicada and related genera.

\section{Order Protodonata}

Very few specimens of this order have been found in the Upper Carboniferous deposits of North America. Up to the present, only five species have been described and all are known by single specimens. These are as follows:

(1) Paralogus aeschnoides Scudder, 1893, Family Paralogidae, from East Providence, Rhode Island (Allegheny Series, comparable to the Upper Westphalian of Europe). (2) Palaeotherates pennsylvanicus Handlirsch, 1906, incertae familiae, from coal beds near Pittsburgh, Pennsylvania (Upper Pottsville, comparable to the Middle Westphalian of Europe). (3) Paralogopsis longipes Handlirsch, 1911, incertae familiae, from near Mazon Creek, Illinois (Carbondale Formation, comparable to Upper Westphalian of Europe). (4) Typus durhami Carpenter, 1960, Family Meganeuridae, from coal beds in Durham, Georgia (Lower Pottsville, comparable to Lower Westphalian of Europe). (5) Oligotypus makowskii Carpenter \& Richardson, 1971, Family Paralogidae, from Pit 11, near Braidwood, Illinois (Carbondale Formation, comparable to the Upper Westphalian of Europe).

We are now able to add a sixth specimen, collected in Schuykil Co., Pennsylvania, and contained in the Klose collection. Although a fragment, consisting of the basal part of a fore wing, the fossil is worthy of a formal description and a specific name. I have assigned the species to the genus Palaeotherates, the family position of which has been very problematical. Since the new species does not provide sufficient additional information to enable a family diagnosis, I still consider the genus incertae familiae.

\section{Palaeotherates Handlirsch, 1906}

The type-species, pennsylvanicus, is known from a distal fragment of a wing with typical protodonate features. Since the new species, described below, is based on a basal fragment of a wing, there is no way of knowing how closely these two species may be related. I have placed the new species here in order to avoid the naming of another genus at this time. 
Palaeotherates analis, n.sp.

Figure 1

Fore wing: length of preserved part of wing, $80 \mathrm{~mm}$; its maximum width, $38 \mathrm{~mm}$. The species differs from pennsylvanicus by its larger size and by the structure of the anal area. It is about twice the size of pennsylvanicus, and the first anal vein (1A), at least the basal half of it, has no major branch.

Type: No. I1028, (K6757) William Penn Memorial Museum, Harrisburg; collected by W.F. Klose II in a strip mine 400 meters east of bench mark 1271 on the St. Clair-Mahanoy City Road, Blythe township, Schuykil County, Pennsylvania; Allegheny Series; underclay Buck Mt. \#5 coal. The specimen consists of the basal twofifths of a fore wing; parts of the wing, especially the anal area, are clearly preserved, but some veins, as RS and CUP are very faint and uncertain. However, the convexities and concavities of the veins are clear and the homologies of the veins are obvious.

The most distinctive feature of the wing is the absence, in the preserved part, of a major branch of 1A. In all other Protodonata known to me, 1A gives rise (at about the level of the peak of the curve in CUP) to a prominent branch, which in turn forms a series of simple branches leading to the hind margin of the wing. This insect was obviously larger than pennsylvanicus, the wing of which has been estimated to be $55 \mathrm{~mm}$ long (Carpenter, 1960). Compari-

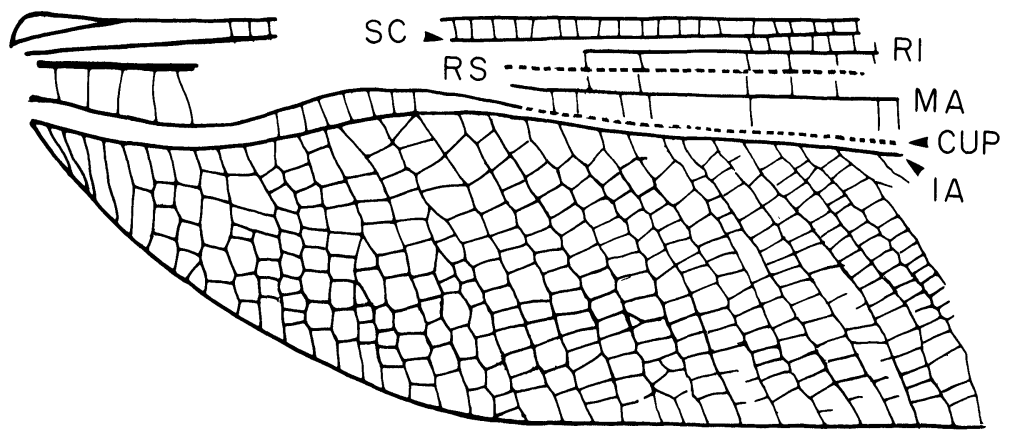

Figure 1. Palaeotherates analis, n.sp. Drawing of preserved part of wing, based on holotype, No. I1028, William Penn Memorial Museum. Length of fragment, $50 \mathrm{~mm}$. $\mathrm{R} 1$, radius; RS, radial sector; MA, anterior media; CUP, posterior cubitus; $1 \mathrm{~A}$, anal vein. 
son with meganeurids suggests that the complete wing of analis was probably about $200 \mathrm{~mm}$ long, indicating a wing expanse of about $420 \mathrm{~mm}$.

I have identified the type specimen as a fore wing on the basis of the slope of the hind margin, the hind wing of protodonates having a broad anal area basally. However, the basal part of the wing of analis 2 widens more abruptly than that of the fore wing of other protodonates so far known, although the base itself is narrow.

As mentioned above, I have placed analis in the genus Palaeotherates in preference to naming a new genus and for the present I consider the shape, size and nature of the anal vein to be specific characteristics. The species is noteworthy as the sixth specimen of Protodonata to be found in the Upper Carboniferous of North America, and as the largest species of that series of fossils.

\section{Order Caloneurodea}

This taxon, chiefly based on the genus Caloneura from the Upper Carboniferous of Commentry, was originally named by Handlirsch (1929) as a suborder of the order Protorthoptera. Martynov (1938), after studying a series of related genera from the Permian of the Soviet Union, elevated the group to an order. Since then, the Commentry species have been revised (Carpenter, 1961) and many other genera and families have been named to receive species from the Permian of the Soviet Union and the Permian and Upper Carboniferous of the United States (Tillyard, 1937; Carpenter, 1943, 1970). Some of the additional species have led to a broadening of the concepts of the order and its relationships. These general topics will be considered in another article dealing with Caloneurodea from the Permian of Oklahoma, but I include here a brief statement of the characteristics of the order, as a preface to the description of a new species contained in the Klose collection and apparently belonging to the order.

Although some of the body structures are known, the order Caloneurodea is based mainly on wings, which show three major characteristics: (1) the homonomous nature of the fore and hind wings, the hind pair lacking an enlarged anal area; (2) the origin of CUA from $M$ near the wing base and its proximity to CUP for most of its length; (3) the numerous cross veins, which are either straight or somewhat reticulate and are very strongly developed and thick, 
forming a series of ridges over the wing surface. Details of the body structures are known only in one species, Paleuthygramma tenuicorne Martynov, 1938, from the Permian of the Soviet Union. The numerous specimens of this species enabled Martynov (1938) and Sharov (1966) to reconstruct its more general features. The antennae were elongate and setaceous; the legs cursorial, very long and slender; and prothorax short and broad; the females possessed short cerci and a short ovipositor; the male abdomen terminated in a pair of foreceps, apparently modified cerci and similar to those of the Dermaptera. Whether or not the body structure of Paleuthygramma was typical of all Caloneurodea, we have no means of knowing at present, but the evidence, such as it is, suggests that the Caloneurodea were specialized members of the orthopteroid complex, considered in its broadest sense. ${ }^{1}$ The order is known from the Upper Carboniferous and Permian of North America, Europe, and Asia.

Only two species of Caloneurodea have been recorded from the Upper Carboniferous of North America. One of these, Caloneurella carbonaria Carpenter, 1934, is from the Freeport Stage, Allegheny Series, South Good Spring Colliery, near Tremont, Pennsylvania; the other, Pseudobiella fasciata Carpenter, 1970, is from the Madera Formation, Desmoinesian Series (comparable to Upper Westphalian of Europe), near Albuquerque, New Mexico. The description of the new species in the Klose collection from Pennsylvania follows.

\section{Family Amboneuridae, new family}

SC terminating on costa well beyond mid-wing; RS arising slightly before mid-wing, with 5 terminal branches; $M$ forked to about half its length; CUA coalesced with $M$ basally, strongly convex, but terminating on the hind margin with a series of twigs; CUP strongly concave, not markedly close to CUA and slightly divergent from it distally. Cross veins very strong and preserved as prominent ridges over the wing surface, those between SC and R1 and between R1 and RS mostly transverse; in other areas the cross veins have frequent anastomoses, forming a very coarse, irregular net-work.

\footnotetext{
'Sharov (1966), however, believed that the Caloneurodea were endopterygote insects related to the Neuroptera.
} 
This family differs from others in the order by the remoteness of CUA from CUP, and by the presence of irregular cells formed by cross veins in several areas of the wing. The closest affinities of the family seem to be with the Permobiellidae.

\section{Amboneura, new genus}

Since only one species is known in the family, a precise generic diagnosis is impossible. Some of the features mentioned below, such as the nature of the forks of the main veins, are probably of generic value.

Type-species: Amboneura klosei, n.sp.

\section{Amboneura klosei, n.sp.}

Figures 2 and $3 \mathrm{~A}$

Length of wing, as preserved, $25 \mathrm{~mm}$; maximum width, $8 \mathrm{~mm}$. Estimated length of complete wing, about $30 \mathrm{~mm}$. R2+3 forked to about one-third of its length; R4+5 forked very shortly after its origin; R4 forked to about half its length, R5 unbranched.

Type: No. I1027, in William Penn Memorial Museum, Harrisburg, Pennsylvania; collected by William F. Klose II (Field no. K6340) in Blythe Township, Pennsylvania; strip mine east of telephone poles 55-56, St. Clair-Mahanoy City Road. Allegheny Series of Pennsylvanian Period; Llewellyn Formation underclay. Buck Mt., \#5 coal. This specimen consists of a nearly complete wing, lacking only the basal fifth; the coastal margin is broken away from the base to mid-wing. The rest of the wing is clearly preserved, with distinct convexities and concavities.

The generic name is derived from the classical Greek words ambon (ridge) and neura (nerves), referring to the ridged cross veins, and is considered neuter plural. The species is named for William F. Klose II, the collector of the specimen, in recognition of his extensive fossil collecting and other aspects of field work done in the coal beds of Pennsylvania.

I have placed this insect in the order Caloneurodea because of the general venational pattern of the wing and the nature of the cross veins. In most respects the venation is strikingly similar to that of Permobiella (figure 3B), from the Permian of Kansas, and to Caloneurella (figure 3C), from the Upper Carboniferous of Pennsylvania. In these two general, RS has only three terminal branches, 


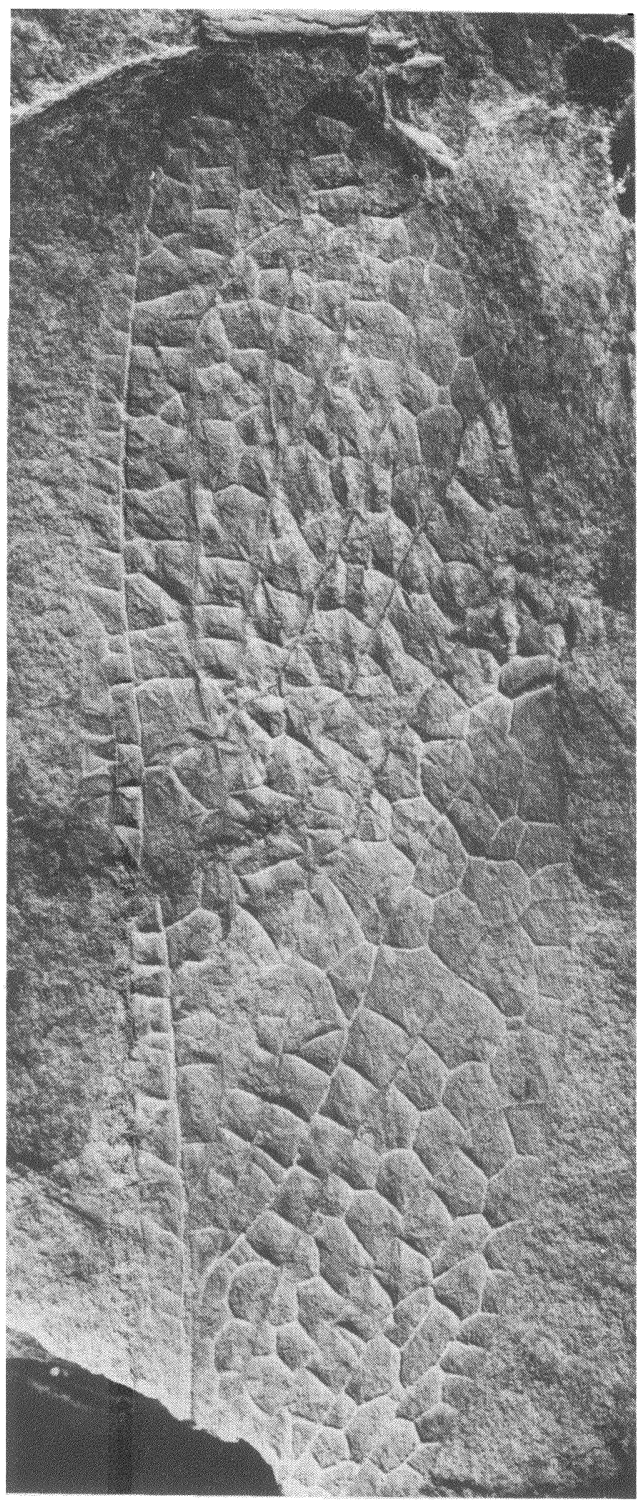


instead of five as in Ambononeura; however, in the other members of the order the branches range from two to six. As in nearly all genera, $\mathrm{M}$ has a single, prominent fork. CUA arises from the base of $\mathrm{M}$, just before the level of origin of RS, and is slightly curved as it runs toward the hind margin, ending somewhat vaguely in association with cross veins at the margin - a feature that occurs in many Caloneurodea, especially the Permobiellidae. The separation of CUA and CUP is greater than in any other members of the order, although not much greater than in the Permobiellidae. The condition in Caloneura itself is of interest in this connection; CUA and CUP are only slightly nearer together than the other veins are to their adjoining veins. The structure in Amboneura is probably the more generalized, since the ancestral stock of the order Caloneurodea presumably had a more normal venational pattern than is present in most of the members of the order as we now know it. It may well be also that the reticulation of some of the cross veins is another generalized trait, since it is present in many Protorthoptera.

The diagnosis of the Caloneurodea, given above, has been slightly changed to permit inclusion of Amboneuridae.

I take this opportunity to discuss the relationships of Caloneurella carbonaria Carpenter, 1934, the only other member of the order Caloneurodea recorded from the anthracite coal fields of Pennsylvania. This was originally placed in the family Caloneuridae, otherwise known only from the Commentry beds of France. At the time of the description of the genus, very few specimens of the order Caloneurodea had been found and their classification was very arbitrary. Since then the Commentry specimens have been revised and the number of known families, genera, and species has tripled. Under the revised definition of the Caloneuridae, Caloneurella can no longer be placed in that family, but it can be appropriately assigned to the Permobiellidae. This family was based on the genus Permobiella from the Permian of Kansas (Tillyard, 1937) and was originally considered to be a subfamily of the Neuroptera. Martynov (1938), recognizing its affinities with the Caloneuridae, transferred it to the Caloneurodea, where it almost certainly belongs (Carpenter, 1943). The family has been characterized by the relatively short SC, which terminates just beyond midwing; by the presence of 3 branches on RS, a deeply forked M, and a slight divergence of CUA and CUP distally (figure 3B). Pseudobiella, the second genus in the family, shares these features. 

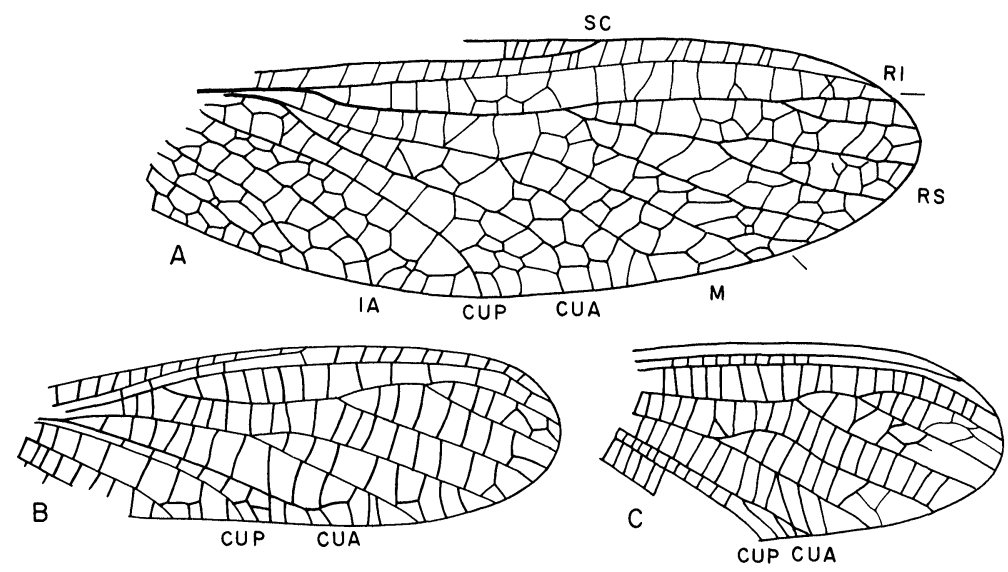

Figure 3. A, Amboneura klosei, n.sp. Drawing of holotype. B, Permobiella perspicua Tillyard, from Lower Permian of Kansas; drawing of fore wing, based on holotype, no. 15593, Peabody Museum. Length of wing as preserved, $11 \mathrm{~mm}$. C, Caloneurella carbonaria Carpenter, from Upper Carboniferous of Pennsylvania; drawing of wing, based on holotype, no. 6894/6895, Carnegie Museum, Pittsburgh. Length of wing, as preserved, $155 \mathrm{~mm}$. SC, subcosta; M, media; CUA, anterior cubitus; other lettering as in figure 1.

Caloneurella carbonaria has the basic venation of the Permobiellidae (figure 3C), except for the structure of SC, which extends well towards the apex of the wing. However, in view of the very close resemblance of Caloneurella to the Permobiellidae in all other respects, so far as known, I now believe the length of SC to be a character at the generic level instead of at the family level and I am placing Caloneurella in the Permobiellidae.

\section{Orders Protorthoptera AND Blattaria}

There is one wing fragment in the Klose collection that is of unusual interest, although it is too incomplete for determination even to order. This is specimen No. I1035 (K6339), now in the William Penn Memorial Museum, from strip mine east of telephone poles 55-56, Blythe Township, under clay of Buck Mt. \#5 anthracite (figure 5). It consists of the distal portion (12 mm long) of a wing with a venation that suggests the Caloneurodea. However, the nature of M, CUA, UP, and $1 \mathrm{~A}$ indicates that the wing was almost certainly very short and broad, in contrast to the wings of the 


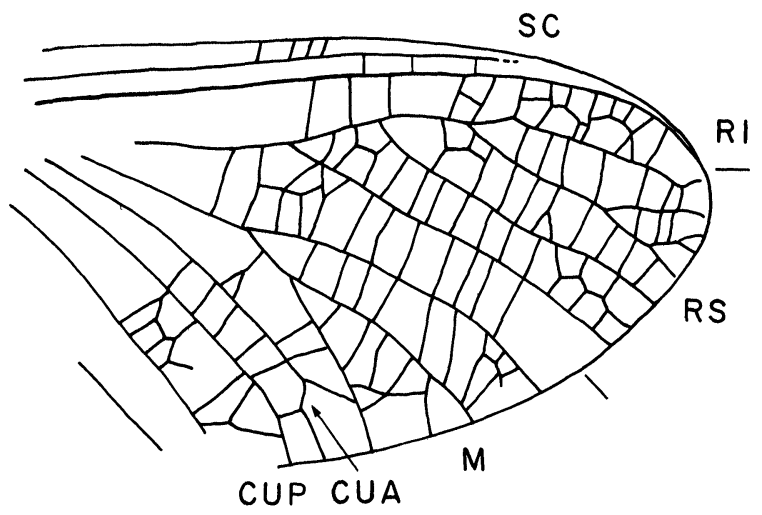

Figure 4. Drawing of specimen no. I1035 (K6339), order uncertain, from Upper Carboniferous of Pennsylvania, near Trenton. Length of wing fragment, $13 \mathrm{~mm}$. Lettering as in figure 3.

Caloneurodea, which were long and slender. It is conceivable that this fossil might be part of a nymphal wing of a protorthopteron or possibly of a caloneurodean.

One specimen, No. I1030 (K6343) in the William Penn Memorial Museum, clearly belongs to the Protorthoptera. It was collected in a strip mine along strike, 500 meters west of Blue Coal Braker, Audenreid Village, Pennsylvania, and under clay of unnamed anthracite, 85 feet above Mammoth anthracite. It consists of the distal half of a fore wing, partially covered by plant fragments (figure 6). The venation is clear enough over the preserved part of the wing, which is $25 \mathrm{~mm}$ long, but since only R1, RS, and part of $\mathrm{M}$ are preserved, naming the species seems pointless, especially since family determination is impossible. The fossil is of interest, however, because it is only the second insect from the anthracite coal field of Pennsylvania that can reasonably be placed in the order Protorthoptera. The other species is Hapaloptera gracilis Handlirsch (see Carpenter, 1965).

The Blattaria, as mentioned above, are by far the most numerous insects in the coal beds. Of the 45 roaches in the collections being studied, 21 are small fragments of fore or hind wings, and nothing can be done with them below the ordinal level. The remaining 24 specimens fall into the families Archimylacridae and Mylacridae, there being 12 in each family. 


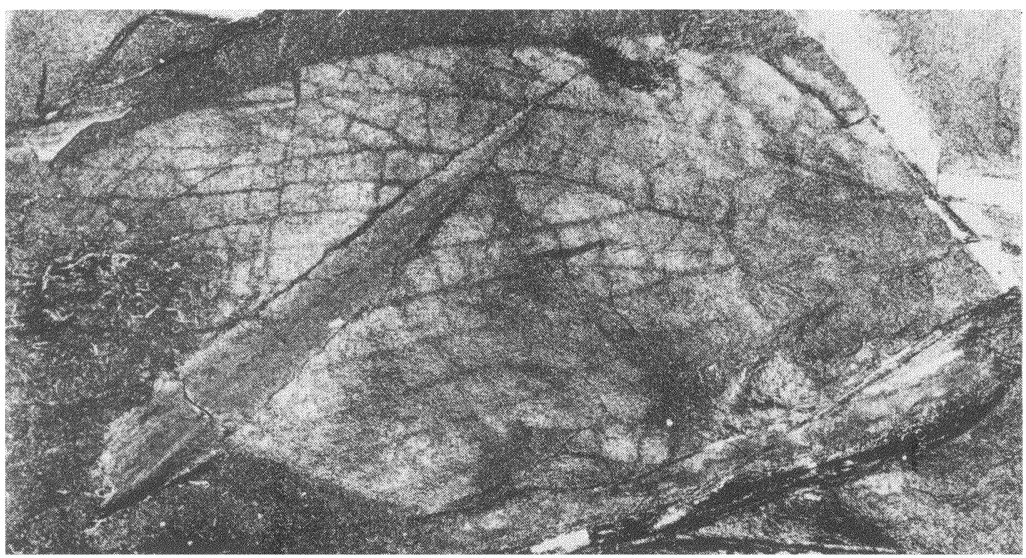

Figure 5. Photograph of protorthopteron, no. I1030 (K6343), William Penn Memorial Museum, from Upper Carboniferous of Pennsylvania, near Audendried Village. Length of wing fragment, $25 \mathrm{~mm}$.

The well-known variability of the venation within species of the Blattaria, both existing and extinct, makes the taxonomy of the fossil roaches, at least of the Palaeozoic species, very difficult, especially since the earlier workers on these fossils did not take the variation into consideration during the course of their studies. Recently, Dr. Jörg Schneider of the Bergakademie Freiberg, DDR, has undertaken a series of studies on Palaeozoic roaches (1977, 1978a, 1978b, 1980), with revised concepts of species, genera, and families. A great deal of specific synonymy seems likely, with perhaps as many as $80 \%$ of the species described from some deposits being placed in synonymy, and with extensive generic synonymy. For this reason and because all of the specimens in the collections at hand consist of wings, without body parts, I have not attempted generic identification. Some of the wings are very well preserved, however, and could be of special interest in connection with revisional studies, such as those being done by Dr. Schneider. Five specimens in the Klose collection are well preserved: No. I1044 (K 7944) is a large fore wing of an archimylacrid, $50 \mathrm{~mm}$. long, collected at Oneida, roof of Mammoth anthracite, Pennsylvania; 
No. I1048 (K 12092) is a small but excellent fore wing of an archimylacrid from Wanamie, Pennsylvania, roof of top split Baltimore anthracite; No. I1025 (K6345) ${ }^{2}$ is the wing of a small mylacrid, from Carbondale, Pennsylvania, roof of Clark anthracite; and No. I1024 (K6334) is a specimen of a mylacrid, consisting of both fore wings and part of a hind wing, from Wanamie, Pennsylvania, roof of top split Baltimore anthracite.

\section{ACKNOWLEDGMENTS}

Partial financial support of this research is gratefully acknowledged to the National Science Foundation, Grant No. DEB8004161, F.M. Carpenter, principal investigator. I am also indebted to Mr. William F. Klose II, for arranging the loans of these specimens; to Dr. Donald Hoff, Curator of Earth Sciences, William Penn Memorial Museum, Harrisburg, Pennsylvania, and Mr. Bruce Dietrich, Director of the Reading Public Museum and Art Gallery, Reading, Pennsylvania, for their cooperation in making the loans; and to Mrs. J. S. Lawless, Peabody Museum, Yale University, for the loan of the type of Permobiella perspicua.

\section{Carpenter, F.M. Literature Cited}

1934. Carboniferous insects from Pennsylvania in the Carnegie Museum and Museum of Comparative Zoology. Ann Carnegie Mus 122:323-341.

1943. The Lower Permian insects of Kansas. Part 9. The orders Neuroptera, Raphidiodea, Caloneurodea, and Protorthoptera (Probnisidae), with additional Protodonata and Megasecoptera. Proc Amer Acad Arts Sci 75:55-84.

1960. Studies on North American Carboniferous insects. 1. Protodonata. Psyche 67:89-110.

1961. Studies on Carboniferous insects from Commentry, France. Part III. The Caloneurodea. Psyche 68:145-153.

1965. Studies on North American Carboniferous insects. 4. The genera Metropator, Eubleptus, Hapaloptera, and Hadentomum. Psyche 12:175-190.

1970. Fossil insects from New Mexico. Psyche 77:400-412.

Carpenter, F. M. and E. S. Richardson, JR.

1971. Additional insects in Pennsylvanian concretions from Illinois. Psyche 78:267-295.

\footnotetext{
${ }^{2}$ The counterpart of this includes the specimen of the Dictyocicada-like insect mentioned above.
} 
Handlirsch, A.

1906. Revision of American Palaeozoic insects. Proc U S Nat Mus 29:661-820.

1911. New Paleozoic insects from the vicinity of Mazon Creek, Illinois. Amer Journ Sci 31:297-326.

1929. Insecta, in Kükenthal, Handbuch der Zoologie, 4(7):687-691. W. Gruyter.

1937. Neue Unterschungen über die fossilen Insekten mit Ergänzungen und Nachträgen sowie Ausblicken auf phylogenetische, paleogeographische und allgemain biologische Probleme. I. Ann Naturhist Mus Wien 48: $1-140$.

MARTYNov, A. V.

1938. Eutdes sur l'histoire geologique et de phylogenie des ordres des insectes (Pterygota) 1. Palaeoptera et Neoptera-Polyneoptera. Trav Inst Paleon Acad Sci USSR 7:1-119 [Russian].

ROHDENDORF, B. B., et al.

1962. [Insecta]. Osnovy Paleontologii: Akademii Nauk SSSR, pp. 1-374. [Russian].

SCHNEIDER, J.

1977. Zur Variabilität der Flügel paläozoischer Blattodea (Insecta), Teil I. Freib Forsch C 326:87-105.

1978a. Idem. Teil II. Freib Forsch C 334:21-39.

1978b. Zur Taxonomie und Biostratigraphie de Blattodea (Insecta) des Karbon und Perm der DDR. Freib Forsch C 340:1-152.

1980. Zur Taxonomie der junpaläozoischer Neorthoblattinidae (Insecta, Blattodea). Freib Forsch C 348:31-39.

Sharov, A. G.

1966. The position of the orders Glosselytrodea and Caloneurodea in the system of insects. Paleon Zhur 1966:(3):84-93.

TillyaRD, R. J.

1937. Kansas Permian insects. Part 17. The order Megasecoptera and additions to the Palaeodictyoptera, Odonata, Protodonata, Protoperlaria, Copeognatha, and Neuroptera. Amer Journ Sci 33:81-110. 

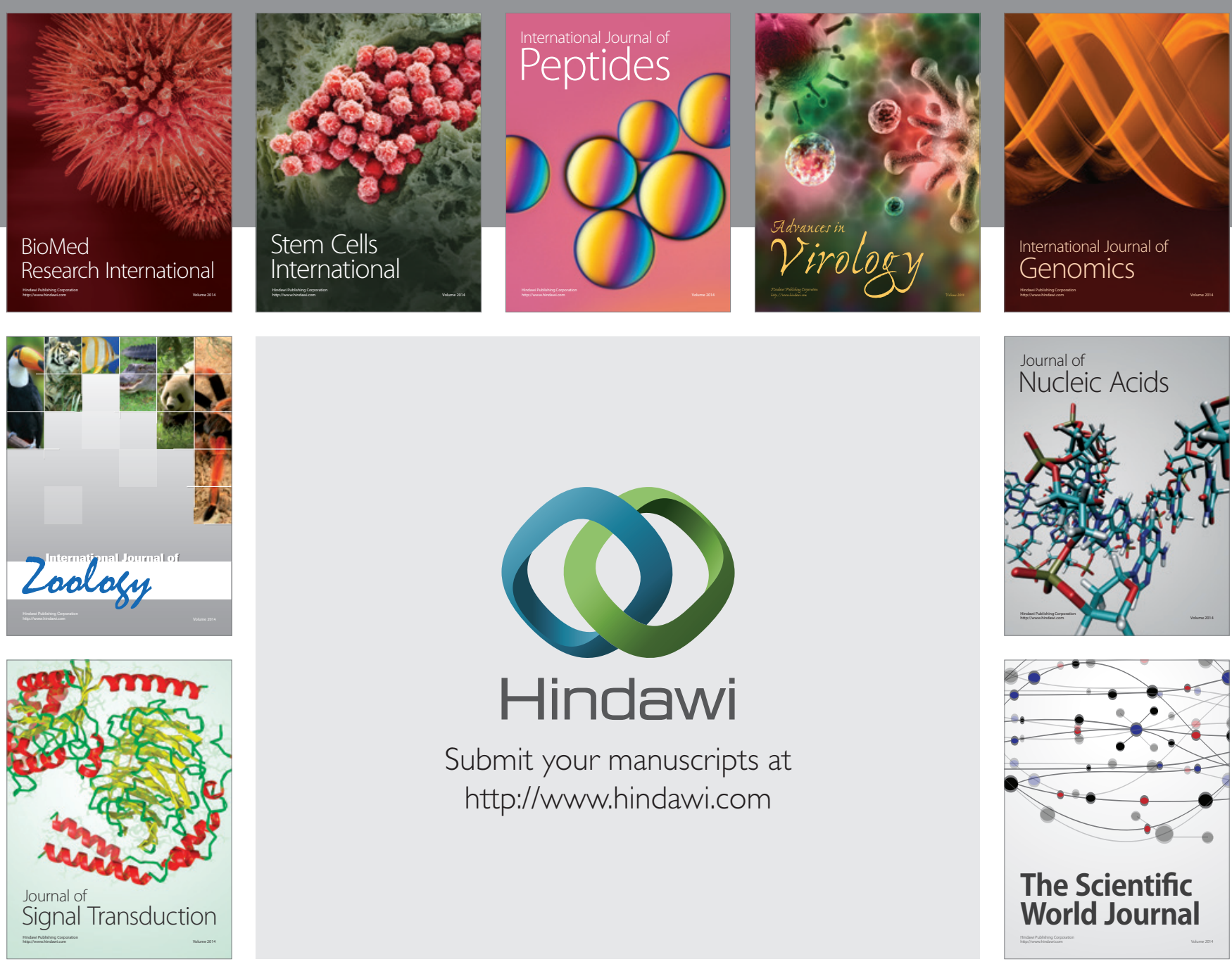

Submit your manuscripts at

http://www.hindawi.com
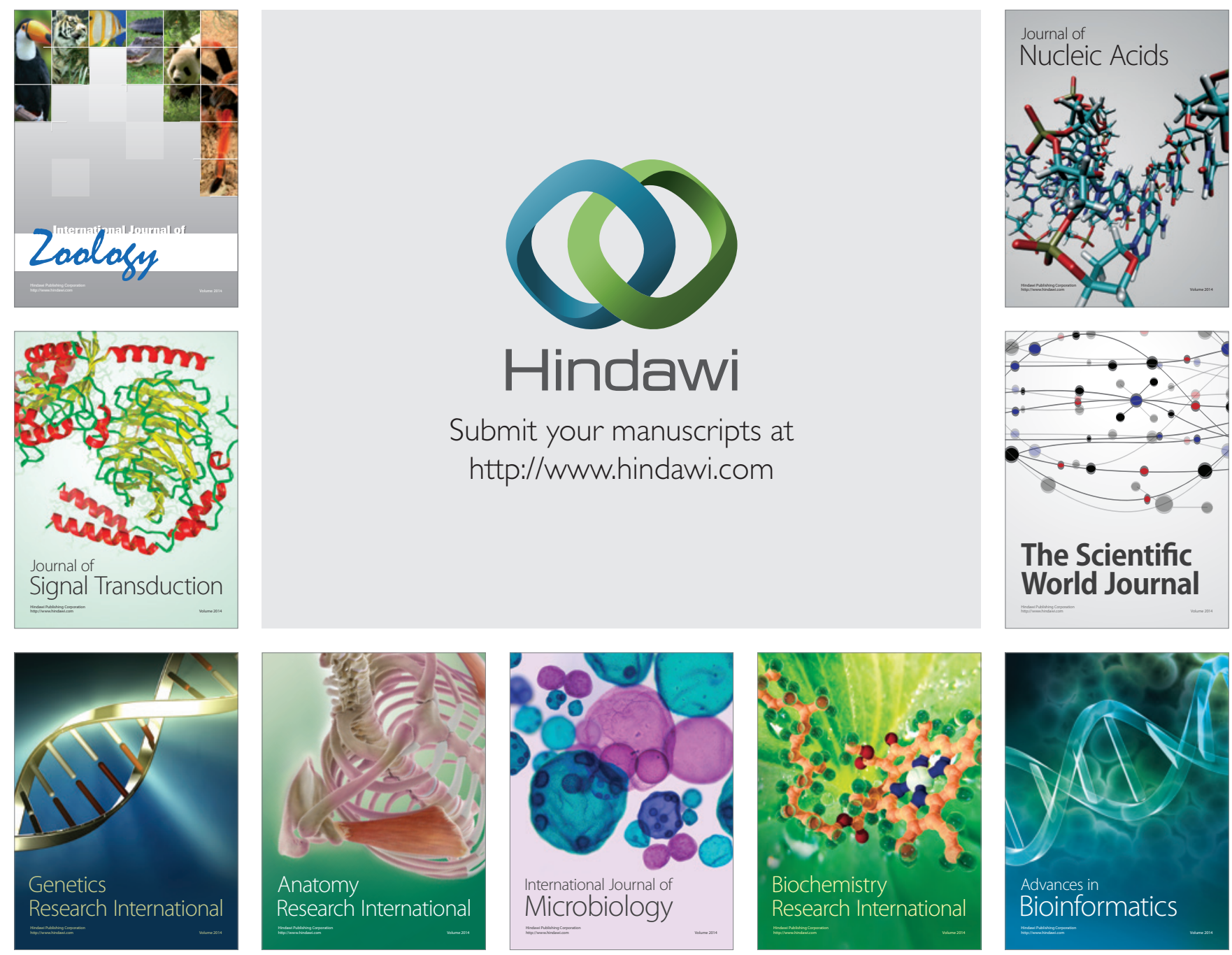

The Scientific World Journal
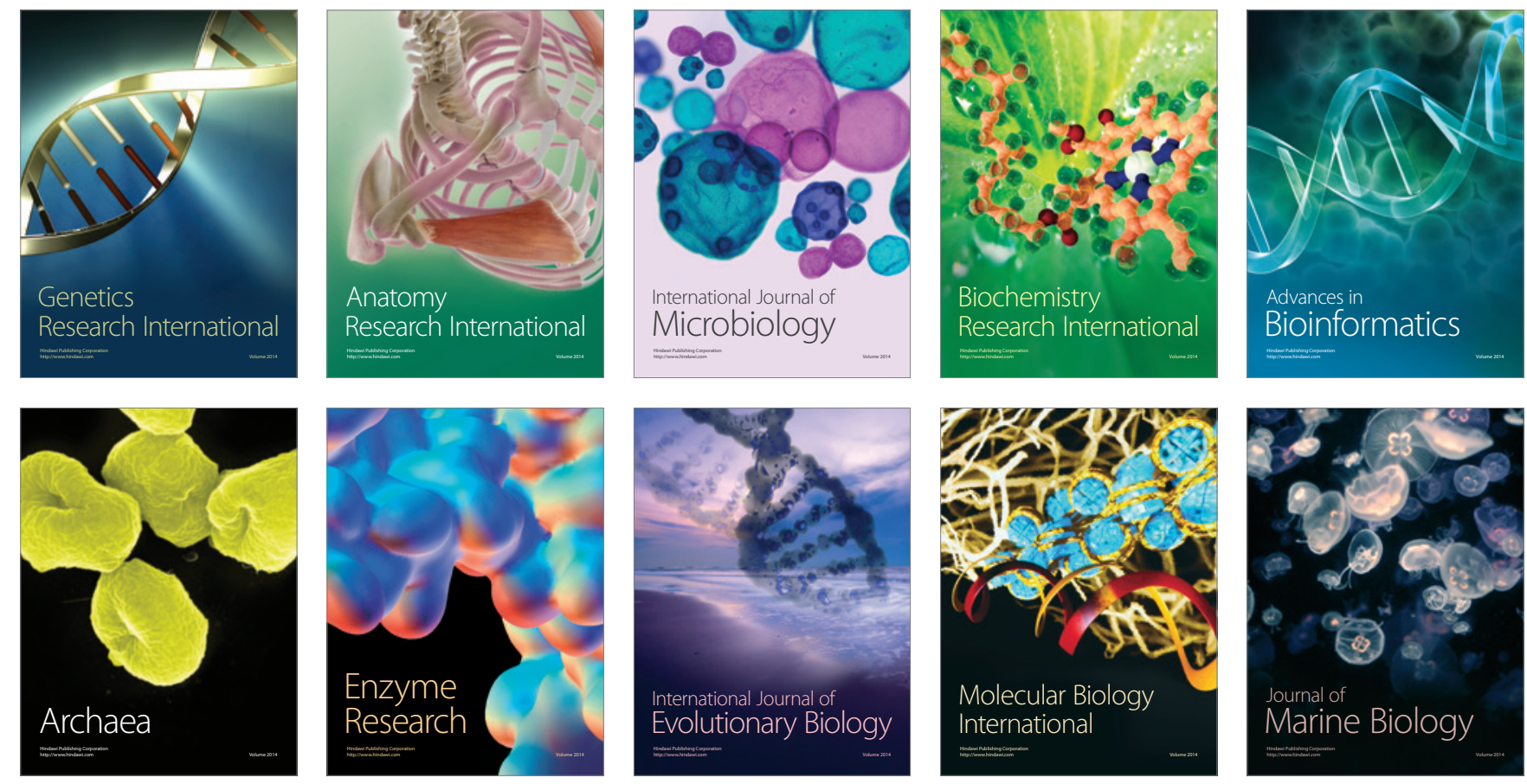